\section{Australian Journal of Crop Science}

AJCS 15(07):977-982 (2021)

doi: 10.21475/ajcs.21.15.07.p2824

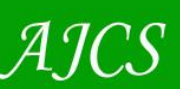

ISSN:1835-2707

\title{
Production of forage palm cultivars (Orellha de Elefante Mexicana, IPA-Sertânia and Miúda) under different salinity levels in irrigation water
}

\author{
Márcia Cristina de Araújo Pereira', Carlos Alberto Vieira de Azevedo ${ }^{1}$, José Dantas Neto $^{1}$, Mariana de \\ Oliveira Pereira*1, Jailton Garcia Ramos ${ }^{1}$, Kheila Gomes Nunes ${ }^{1}$, Gustavo Bastos Lyra², Luciano Marcelo \\ Fallé Saboya ${ }^{1}$
}

\author{
${ }^{1}$ Federal University of Campina Grande, Academic Unit of Agricultural Engineering, Campina Grande, 58.109-970, \\ Paraíba, Brazil \\ ${ }^{2}$ Federal Rural University of Rio de Janeiro, Department of Environmental Sciences, Forest Institute, Seropédica, \\ 23.897-000, Rio de Janeiro, Brazil
}

*Corresponding author: marianapereira.agri@gmail.com

\begin{abstract}
Brazilian semiarid region is characterized by irregular rainy periods that limits the production of forage feed for the maintenance of agricultural livestock and causes losses in the production. Despite that, semiarid region stands out in the production of forage palm, buffering the impact of drought in the area. Thus, this study aimed at analyzing the effect of different levels of salinity in irrigation water on the production of forage palm in the semiarid region. The experiment was arranged as a complete randomized block, in a $4 \times 3$ factorial arrangement and four levels of salinity $\left(0.2,2.0,3.8\right.$ and $\left.5.6 \mathrm{dS} \mathrm{m}^{-1}\right)$; three cultivars (Miúda, Orelha de Elefante Mexicana and IPA-Sertânia) with 4 replications. The variables evaluated were the following: number of primary, secondary, tertiary and total cladodes, cladode biomass and estimative of threshold salinity (SL). The results showed that irrigation with saline water with an electrical conductivity of $2.0 \mathrm{dS} \mathrm{m}^{-1}$ negatively affected the emission of cladodes of superior orders for all forage palm cultivars. Miúda cultivar presented the best production of fresh phytomass ( $13.36 \mathrm{~kg}$ per plant) under a salinity level of $4.04 \mathrm{dS} \mathrm{\textrm {m } ^ { - 1 }}$, followed by Orelha de Elefante Mexicana (12.55 kg per plant) under a salinity level of $2.73 \mathrm{dS} \mathrm{m}^{-1}$ and Baiana (11.56 kg per plant) under a salinity level of $2.17 \mathrm{dS} \mathrm{m}^{-1}$.
\end{abstract}

Keywords: Opuntia; Napolea; water electrical conductivity; salinity threshold.

Abbreviations: ECW_Water electrical conductivity; NPC_Number of primary cladodes; NSC_number of secondary cladodes; NTC Number of tertiary cladodes; TNC_ Total number of cladodes; DPC_Dry phytomass of cladodes; FPC_Fresh phytomass of cladodes.

\section{Introduction}

Brazilian semiarid covers $70 \%$ of the northeast region and it is characterized by irregular rainfalls and high evapotranspiration rates, which affect forage availability and its quality in this area (Dubeux Júnior et al., 2010). In this context, forage species that withstand to long dry-seasons in conditions of low water availability, presenting high biomass production in a slightly soil fertile, can be of great importance for the livestock of the region (Lima et al., 2018; Alves et al., 2007).

In this way, forage palm genus Opuntia fícus indica and Napolea cochenillifera Salm Dyck) are the most important forage species for the producers, since they present high production, excellent energetic food, high digestibility, and a hydric resource for animals (Lima et al., 2015). It is characterized by its mechanism CAM (crassulacean acid metabolism), which enables a better management of water, containing $90 \%$ of it in its cladodes, representing a great contribution for animals. This results in water economy due to the closure of stomata during the day and its opening during the night, with the fixation of $\mathrm{CO}_{2}$. Even being considered an adapted crop, the productivity of forage palm has been low, mainly due to a lack of proper management (Donato et al., 2014). Besides that, it is characterized for being a rustic cactus, having a high energetic value, and a resistance to dry seasons (Bezerra et al., 2015).

Although forage palm has adapted well to soil and climate conditions of Brazilian northeast semiarid region, this plant presents a great potential in water availability conditions. Thus, irrigation is an important practice in a safe agriculture production, mainly in drought and hot areas and high rates of potential evapotranspiration, which exceed precipitation rate most part of the year by reducing water in plants. However, low access to safe water in semiarid regions determines irrigated agriculture and livestock development. In this context, the use of saline water in adapted crops might be an alternative to improve productivity rates in the region (Galvão Júnior et al., 2014; Holanda et al., 2016).

Saline water has been gaining space as a viable alternative to obtain an adequate production. Some studies with saline water have been carried out over 6 years at the Experimental 
Station, in the municipality of Pedro Avelino, Rio Grande do Norte. Forage palm has been monitored and irrigated with an electrical conductivity of $5 \mathrm{dS} \mathrm{m}^{-1}$ (high salinity and chloride levels) and even in these conditions, high levels of productivity were achieved without damaging soil (Lima et al., 2015).

Studies concerning irrigation with saline waters in arid and semiarid regions is of great importance, since most available water in these regions is saline or brackish water. In this context, studies that aim at analyzing cultivars with a viable production under saline water conditions are relevant to the development of agriculture in the arid and semiarid region seeking out estimate the salinity threshold of forage palm in these conditions. In this regard, this work aimed to evaluate the effect of different levels of salinity in irrigation water on the production of forage palm cultivars in the Brazilian semiarid region.

\section{Results and discussion}

\section{Effect of salt in water irrigation on the production of forage} palm cultivars

The results show significant effects $(p<0.01)$ by $F$ test (Table 1) for individual factors of forage palm cultivars and for salinity levels in irrigation water on every variable evaluated. For the interaction between the factors analyzed, there was a significant effect $(p<0.05)$ for the number of primary cladodes (NPC) and $(p<0.01)$ for the number of secondary cladodes (NSC), tertiary cladodes (NTC), and total number of cladodes (TNC).

Figure $1 \mathrm{~A}$ shows that the slicing interaction of salinity and cultivars was significant at $0.01(p<0.01)$ of probability for Baiana and Miúda cultivars. According to regression equation, there was a linear effect with an increase of $6.31 \%$ and $8.62 \%$ with an increment of $1 \mathrm{dS} \mathrm{m}^{-1}$ in water irrigation on Miúda and Baiana cultivars, respectively. On the other hand, Orelha de Elefante Mexicana did not present significant effects when salinity varied, showing an average value of 6.44 for the four levels of salinity on primary cladodes per plant. Silva (2017) observed the same when evaluated the growth of forage palm (Orelha de Elefante Mexicana and Baiana) irrigated with saline water, having a liner increase of primary cladodes around 0.6 per plant over 112 days of forage palm cultivation, value inferior than the one found in the present study.

Regarding the number of secondary cladodes (NSC), Figure 1B shows that the slicing interaction of salinity and cultivars was significant for the three cultivars analyzed, however the mathematical model that best adjusted to Miúda and Baiana was the quadratic polynomial, and for Orelha de Elefante Mexicana was the linear model. The greatest number of secondary cladodes using the adjustment equation on Miúda cultivar was $1.12 \mathrm{dS} \mathrm{m}^{-1}$, presenting a reduction of $86.03 \%$. Baiana showed a reduction of $94.35 \%$ in relation to the highest level of salinity while Orelha de Elefante Mexicana presented a decrease of $15.74 \%$ when salinity increased in irrigation water. The emission of the number of secondary cladodes of Miúda, Baiana, and Orelha de Elefante Mexicana cultivars was affected due to the increase of salinity levels. Freire (2012) evaluated clones of forage palm (Miúda cultivar) and concluded that plants presented lower number of secondary cladodes when irrigated with a saline water of 3.6 $\mathrm{dS} \mathrm{m} \mathrm{m}^{-1}$ when compared to other levels of salinity $\left(0.3 \mathrm{dS} \mathrm{m}^{-1}\right.$, $0.5 \mathrm{dS} \mathrm{m}^{-1}$ and $1.5 \mathrm{dS} \mathrm{m}^{-1}$ ). These results were inferior to the values found for the same cultivar in the present study, which presented the lowest average number of secondary cladodes for the highest salinity level $5.6 \mathrm{dS}^{-1}$.

For tertiary cladodes, the slicing interaction of salinity was significant for Baiana and Miúda cultivars, whereas Orelha de Elefante Mexicana was not influenced by saline water, presenting an average value of 0.18 of tertiary cladodes in relation to the four saline levels evaluated.

Miúda and Baiana cultivars had the greatest emission of tertiary cladodes for the lowest salinity level. With the increase of $1 \mathrm{dS} \mathrm{m}^{-1}$ in salinity levels, there was a reduction of $11.37 \%$ for Miúda cultivar and $60.32 \%$ for Baiana (Figure $2 \mathrm{~A}$ ). Morphological characteristics of forage palm depend most often on the species particularities (Napolea and Opuntia), which probably occurred in the present study, since Baiana and Miúda emitted tertiary cladodes.

For the total number of cladodes, regarding the slicing interaction of salinity and cultivars, it was observed a quadratic behavior for Miúda and Baiana cultivars, on the other hand, Orelha de Elefante Mexicana showed a linear behavior. Miúda reached its peak of total cladodes at $1.08 \mathrm{dS}$ $\mathrm{m}^{-1}$, presenting a reduction of the total number of cladodes $(70.85 \%)$ in relation to the highest level of salinity. Baiana presented a reduction of $1 \mathrm{dS} \mathrm{m}^{-1}$ in relation to the highest level of salinity (79.3\%). Orelha de Efefante Mexicana showed the highest total number of cladodes when irrigated with the lowest level of salinity, decreasing $11.42 \%$ due to the increase of $1 \mathrm{dS} \mathrm{m}^{-1}$ in salinity water (Figure $2 \mathrm{~B}$ ).

In general, most of plants share salt with old leaves and they fall accordingly to the increase of salt. In the present study, it may have occurred to the primary cladodes (modified stalks) that enable the process of photosynthesis, decreasing plant transpiration, and saving water. Thus, forage palm probably compartmentalizes these salts with the primary cladodes, which contributes to a decrease in the emission of superior orders.

Munns (2002) states that the redistribution of salts from leaves to other organs of plants can conserve these salts on the leaves, even being lower than the salt quantity that reaches the transpiration water flux.

According to Silva et al. (2010), the reduction in the number of leaves, probably, is related to toxic effects in $\mathrm{Na}^{+}$and $\mathrm{Cl}^{-}$ ions in the cellular metabolism of palm. Franco-Salazar and Véliz (2008) studied the effects of salinity on the growth, titratable acidity, and concentration of chlorophyll in Opuntia ficus indica (L.) Mill, and observed that the total number of cladodes and apical roots at 60 and 70 days decreased significantly due to the application of sodium chloride $(\mathrm{NaCl})$ on treatments with the highest saline levels (100 and $150 \mathrm{~mol}$ $\mathrm{m}^{-3} \mathrm{NaCl}$ ) after 30 days $(\mathrm{p}<0.05)$; there was an adverse effect in the formation and growth of new cladodes due to the increase of salinity in irrigation water.

\section{Effect of salt in water irrigation on cladode phytomass of forage palm cultivars}

There were significant effects $(p<0.01)$ using $F$ test (Table 2$)$ in the levels of salinity in irrigation water on fresh phytomass of cladodes (FPC), except for dry phytomass of cladodes (DPC). Regarding palm cultivars, there was a significant effect $(p<0.01)$ on every variable evaluated. The interaction between the studied factors presented a significant effect ( $p$ $<0.01$ ) only to fresh phytomass of cladodes (FPC) and did not affect dry phytomass of cladodes (DPC). 
Table 1. Summary of variance analysis for all variables evaluated of Miúda, Orelha de Elefante Mexicana, and Baiana cultivars: plant height (PH) plant width (PW), number of primary cladodes (NPC), number of secondary cladodes (NSC), number of tertiary cladodes (NTC), and total number of cladodes (TNC).

\begin{tabular}{|c|c|c|c|c|c|}
\hline \multirow[t]{2}{*}{ Variation source } & \multirow[t]{2}{*}{ DF } & \multicolumn{4}{|c|}{ Quadratic Average (QA) } \\
\hline & & NPC & NSC & NTC & TNC \\
\hline Cultivar & 2 & $4.52^{*}$ & $273.94^{*}$ & $0.48^{*}$ & $338.52^{*}$ \\
\hline Salinity & 3 & $4.36^{*}$ & $1587.35^{*}$ & $1.55^{*}$ & $1670.14^{*}$ \\
\hline Int. (Cult. x Sal.) & 6 & $1.63^{* *}$ & $185.02^{*}$ & $0.46^{*}$ & $196.07^{*}$ \\
\hline Block & 3 & $0.58^{\text {ns }}$ & $8.19^{\text {ns }}$ & $0.02^{\text {ns }}$ & $6.02^{\text {ns }}$ \\
\hline Error & 3 & 0.55 & 4.87 & 0.02 & 5.08 \\
\hline CV (\%) & - & 12.31 & 12.39 & 16.01 & 9.19 \\
\hline General average & - & 6.04 & 17.81 & 0.99 & 24.54 \\
\hline
\end{tabular}

${ }^{\mathrm{n} s}$ - not significant at 1 and $5 \%$ of probability using $\mathrm{F}$ test; ${ }^{*},{ }^{* *}$ Significant at 1 and $5 \%$ of probability, respectively, using $\mathrm{F}$ test. NTC - transformed data by square root of $\mathrm{Y}+0.5-$ SQRT $(\mathrm{Y}+0.5)$.

(A)

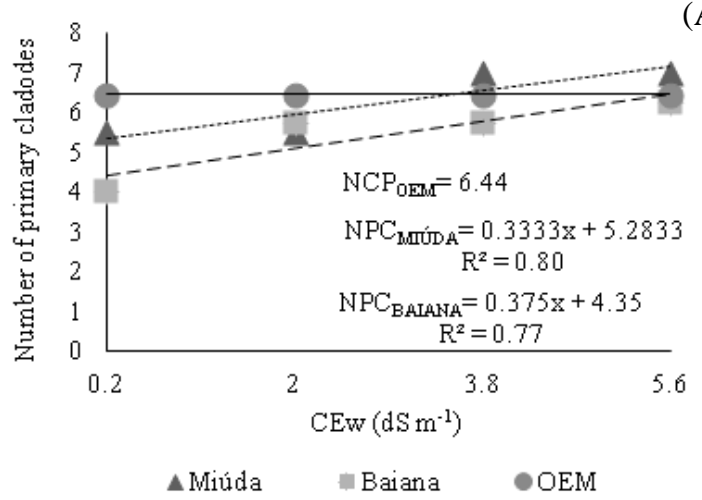

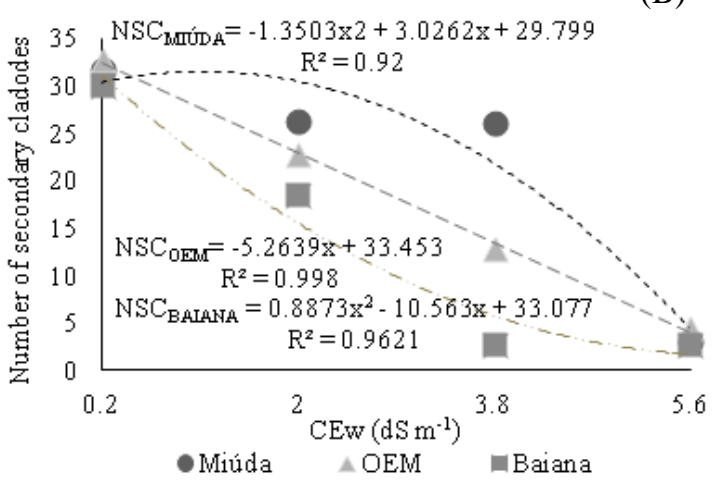

Fig 1. Number of primary cladodes (A) and number of secondary cladodes (B) under salinity levels in irrigation water on each forage palm cultivar.

Table 2. Summary of variance analysis for fresh phytomass of cladodes (FPC) and dry phytomass of cladodes (DPC).

\begin{tabular}{|c|c|c|c|}
\hline \multirow[t]{2}{*}{ Variation source } & \multirow[t]{2}{*}{ DF } & \multicolumn{2}{|c|}{ Quadratic Average (QA) } \\
\hline & & FPC & DPC \\
\hline Salinity & 3 & $8572358.333^{*}$ & $51999.644^{\text {ns }}$ \\
\hline Cultivar & 2 & $6800575.00^{*}$ & $638968.222^{*}$ \\
\hline Salinity $x$ cultivar & 6 & $14366458.33^{*}$ & $23727.584^{n s}$ \\
\hline Block & 3 & $658169.44 \mathrm{~ns}$ & $55461.121 \mathrm{~ns}$ \\
\hline Error & 33 & $376425.505^{\mathrm{ns}}$ & $34106.838 \mathrm{~ns}$ \\
\hline CV (\%) & - & 5.98 & 26.91 \\
\hline General average (g) & - & 10266.25 & 686.257 \\
\hline
\end{tabular}

- not significant at 0.05 of probability using F-test; * Significant at 0.01 of probability, respectively, using $\mathrm{F}$ test.

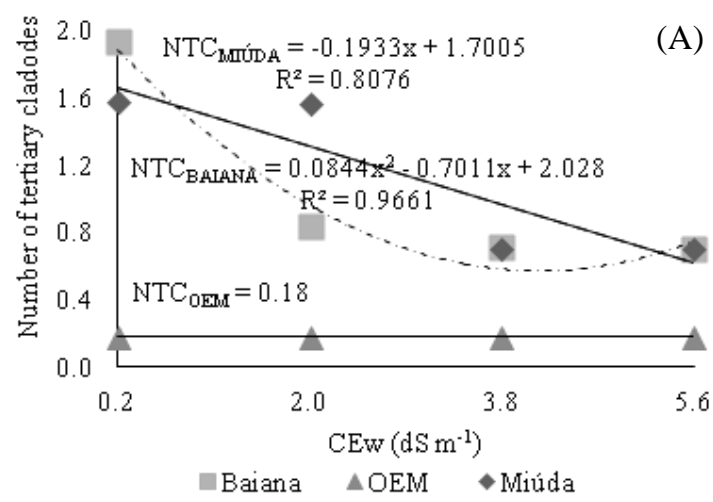

Fig 2. Number of tertiary cladodes (A) and total number of cladodes (B) under the slicing interaction of salinity levels in irrigation water and different forage palm cultivars.
(B)

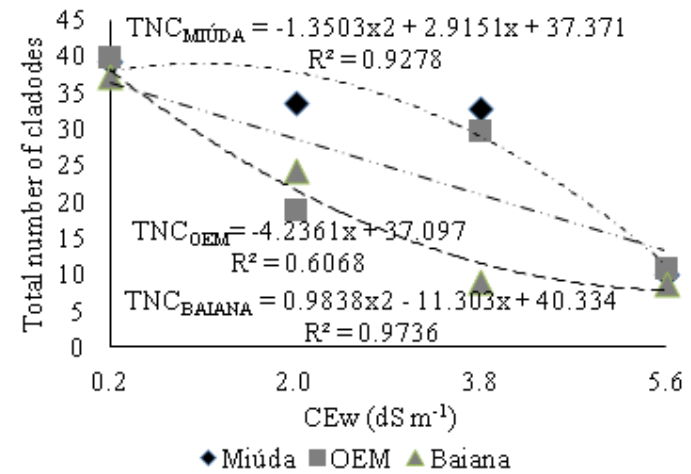



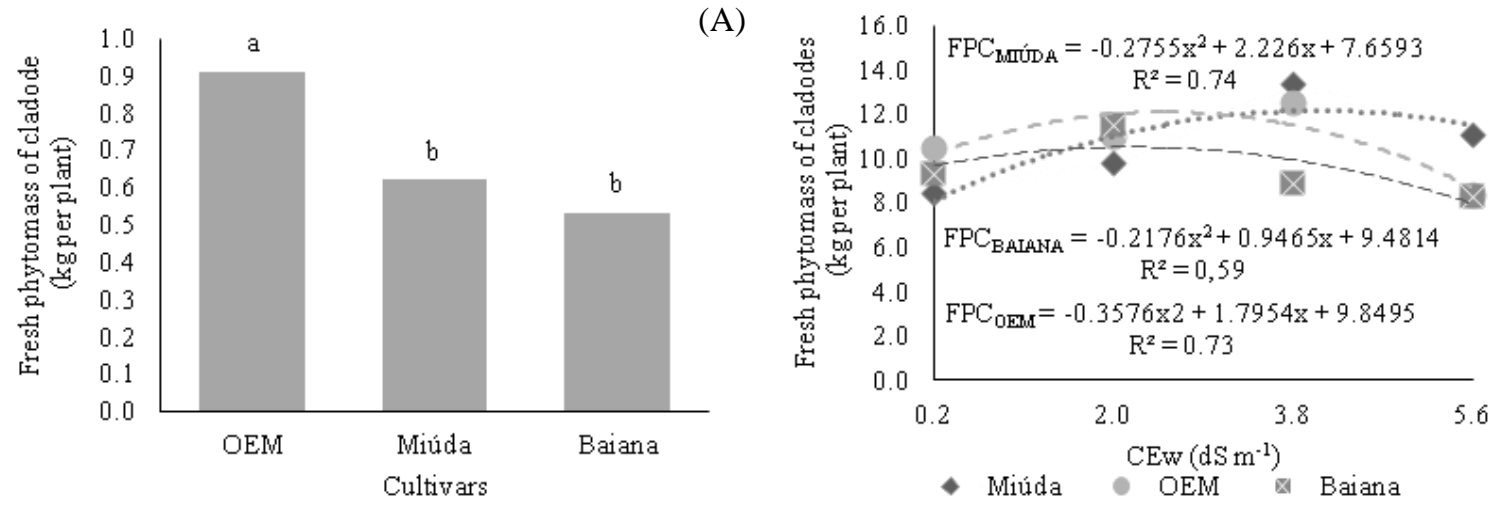

Fig 3. Dry phytomass of cladodes (A) and fresh phytomass of cladodes (B) under the slicing interaction of salinity levels in irrigation water and different forage palm cultivars.

Dry phytomass of cladodes differed significantly for Orelha de Elefante Mexicana and Miúda cultivars; however, Miúda did not differ from Baiana. According to the comparison of means test, Orelha de Elefante Mexicana obtained the greatest value of FPC, with a difference of $0.29 \mathrm{~kg}$ when compared to Miúda cultivar. On the other hand, Baiana cultivar had a difference of $0.38 \mathrm{~kg}$. In this regard, Baiana cultivar was the most negatively affected by salt stress, showing a sensibility to saline water when compared to Orelha de Elefante Mexicana and Miúda (Figure 3A). The same behavior was observed by Silva et al. (2015) with inferior values of dry phytomass for each cultivar evaluated, with average values of dry phytomass of $10.7 \mathrm{t} \mathrm{ha}^{-1}$ for Baiana, $11.5 \mathrm{t} \mathrm{ha}^{-1}$ for Miúda, and $15.6 \mathrm{t} \mathrm{ha}^{-1}$ for Orelha de Elefante Mexicana.

Rego et al. (2014) studied Miúda cultivar after 12 months of regrowth, considering different intensities of harvest and doses of organic fertilization $\left(20 \mathrm{mg} \mathrm{ha}^{-1}\right.$ year ${ }^{-1}$ and $60 \mathrm{mg}^{-}$ 1 year $^{-1}$ ) and obtained a production of dry matter around $146.05 \mathrm{mg} \mathrm{ha}^{-1}$ and $253.80 \mathrm{mg} \mathrm{ha}{ }^{-1}$, respectively). These results refer to the number of primary and secondary cladodes, which represent average values of 15.18 and 25.91 $\mathrm{mg} \mathrm{ha}^{-1}$, showing values around 0.3 and $0.52 \mathrm{~kg}$ of dry matter per plant.

The increase of salinity in irrigation water negatively affected fresh phytomass of cladodes according to regression equation (Figure 3B). A quadratic response is verified for three cultivars: the maximum production of FPC was estimated for Miúda cultivar $(13.36 \mathrm{~kg})$ under an electrical conductivity of $4.04 \mathrm{dS} \mathrm{m}^{-1}$, Baiana obtained a maximum production of FPC $(11.56 \mathrm{Kg})$ with an electrical conductivity of $2.17 \mathrm{dS} \mathrm{m}^{-1}$, and Orelha de Elefante Mexicana with the greatest production of FPC (12.55 kg) under an electrical conductivity of $2.73 \mathrm{dS} \mathrm{m}^{-1}$. An estimation of threshold salinity of each forage palm cultivar was obtained using the adjustment equation of fresh phytomass of cladodes $\left(y=-0.2755 x^{2}+2.226 x+7.6593\right.$ for Miúda; $y=-0.3576 x^{2}+1.7954 x+9.8495$ for OEM; $y=-0.2176 x^{2}+0.9465 x+9.4814$ for Baiana), by deriving these equations.

Dantas (2015) studied saline water depths (0 to $30 \mathrm{~mm}$ month $^{-1}$ ), with an irrigation interval of 10 days, and doses of organic fertilization ( $0 ; 25$ and $50 \mathrm{Mg} \mathrm{ha}^{-1}$ year $^{-1}$ ) in the production of Miúda cultivar. The results show average values for the production of green matter (5.72 and $9.56 \mathrm{~kg}$ ), per

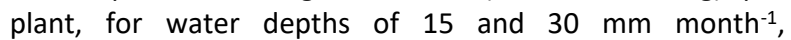
respectively, with an electrical conductivity of $5.25 \mathrm{dS} \mathrm{m}^{-1}$.
The aforementioned author reports that, even being restricted, water is a very important resource in the production of palm.

Nunes (2015) states that salinity levels of 0.76 and $2.0 \mathrm{dS} \mathrm{m}^{-1}$ represent low values and, consequently, several species of plants are able to grow and develop themselves. However, some crops under values higher than $2.0 \mathrm{dS} \mathrm{m}^{-1}$ may not develop in terms of production, for example, some forage palm cultivars (Silva et al., 2014).

Lima et al. (2015) developed researches at the Agricultural Research Corporation of Rio Grande do Norte (EMPARN), located in the Experimental Station of Terras Secas, in areas irrigated with saline water of $5 \mathrm{dS} \mathrm{m}^{-1}$, and high levels of choride during 6 years, and observed high production without compromising soil quality.

Salinity thresholds were estimated for Miúda (4.04 dS m-1), Orelha de Elefante Mexicana ( $2.73 \mathrm{dS} \mathrm{m}^{-1}$ ), and Baiana (2.17 $\left.\mathrm{dS} \mathrm{m}^{-1}\right)$. Thus, Miúda cultivar tolerates higher saline levels, without losses in the production, when compared to the other cultivars evaluated.

Lacerda et al. (2016) highlighted that salinity threshold is the highest level of salinity in the root zone that plants can tolerate without affecting their development and being able to achieve a potential performance of $100 \%$ for the crop. From the value of salinity threshold, the growth may decrease linearly when saline values are increased into soil.

According to Dias et al. (2016), distinct species and plant cultivars respond differently for negative effects of salts, each specie or cultivar present a limit for the addition of salt without decreasing the production.

\section{Materials and methods}

\section{Experiment localization and treatments}

The study was conducted during the period of November 2016 and July 2017, in pots used as drainage lysimeters under field capacity, at the Technology and Natural Resource Center in the Federal University of Campina Grande, located in a harsh mesoregion of Paraiba, situated by geographic coordinates $7^{\circ} 15^{\prime} 18^{\prime \prime}$ latitude $S, 35^{\circ} 52^{\prime} 28^{\prime \prime}$ of longitude W and altitude of $550 \mathrm{~m}$. Experimental design was randomized block in a factorial scheme $4 \times 3$, with 4 replications. The treatments were the following: $\left(\mathrm{S}_{1}=0.2 ; \mathrm{S}_{2}=2.0 ; \mathrm{S}_{3}=3.8\right.$ and $\mathrm{S}_{4}=5.6 \mathrm{dS} \mathrm{m}^{-1}$ ) in the irrigation water; and three palm cultivars: Miúda or Doce (Nopalea cochenillifera Salm Dyck), 
Orelha de Elefante Mexicana (Opuntia stricta (Haworth) Haworth), Baiana or IPA-Sertânia (Nopalea cochenillifera Salm Dyck).

Cladodes of three cultivars of forage palm evaluated in the experiment were collected from Poço de Pedra farm. Cultivars were identified as: V1 - Miúda or Doce; V2 - Orelha de Elefante Mexicana (OEM) and V3 - Baiana or IPA-Sertânia. After receiving a cut, cladodes remained for 15 days in shadow to remove excess moisture and heal injuries caused by the cutting process in order to reduce the incidence of diseases. After 15 days, they were treated with Bordeaux mixture (Motta, 2016) applied before planting.

\section{Experimental setup and procedure}

Commercial sodium chloride (without iodine), calcium chloride, and magnesium chloride were added to the local tap water $\left(C E=1.7 \mathrm{dS} \mathrm{m}^{-1}\right)$, in the proportions $7: 2: 1$, being adjusted to the available tap water concentrations in order to increase electrical conductivity, according to the methodology proposed by Richards (1954). Dissolutions were made using polyethylene pots $(500 \mathrm{~L})$ and each pot received a different saline level.

Treatments were applied when plants were settled and the primary cladode was available in each plant around 100 days after their stabilization, taking into consideration that this crop has an annual cycle.

To carry out the experiment, pots $(120 \mathrm{~L})$ were used with a layer of crushed stone, covered with a textile fabric, a layer of coarse sand, and $0.120 \mathrm{~m}^{3}$ of soil. The soil was obtained from Poço de Pedra farm, PB 233, located in the countyside of Santa Luzia (PB). The physic-chemical characterization of soil was performed in the Irrigation and Salinity Laboratory (LIS) of the Federal University of Campina Grande: $\mathrm{Ca}^{2+}(5.49 \mathrm{cmolc}$ $\left.\mathrm{dm}^{-3}\right), \mathrm{Mg}^{2+}\left(11.41 \mathrm{cmolc} \mathrm{dm}^{-3}\right), \mathrm{Na}^{+}\left(0.14 \mathrm{cmolc} \mathrm{dm}^{-3}\right), \mathrm{K}^{+}(1.86$ cmolc $\left.\mathrm{dm}^{-3}\right),\left(\mathrm{Al}^{3+}+\mathrm{H}^{+}\right)=0$ cmolc dm${ }^{-3} ; \mathrm{pH}$ (water 1:2.5) $=$ 6.97; $\operatorname{CEs}\left(\mathrm{dS} \mathrm{m}^{-1}\right)=0.64$; organic matter $(\%)=1.2$; sand $(\%)=$ 91.34 , silt $(\%)=7.1$ and clay $(\%)=1.56$; bulk density $\left(\mathrm{g} \mathrm{cm}^{-3}\right)=$ 1.42; humidity $(\%)=0.49$ and available water $(\%)=6.37$.

After filling the pots, humidity level of soil increased to field capacity and it was maintained during the period of the study, being irrigated every 10 days. The volume applied and estimated by water balance corresponded to: the amount of applied water minus the volume of drained water of the previous irrigation.

\section{Variables analyzed}

At 234 days after sowing, palm cultivars were submitted to the evaluation of the following parameters: number of primary cladodes (NPC), number of secondary cladodes (NSC), number of tertiary cladodes (NTC), and total number of cladodes (TNC). At 235 days after sowing, primary and secondary cladodes were cut, leaving only the basal cladode in order to determine fresh phytomass of cladodes (FPC) and dry phytomass of cladodes (DPC).

Cladodes were removed with a knife and stored into paper bags, identified, and weighted in a digital balance to determine total biomass of cladodes per plant. Afterwards, the cladodes were kept in a greenhouse during 10 days to remove excess moisture and, after this period, cut in small pieces to facilitate drying, put in identified paper bags, and kept in a greenhouse with a forced-air dryer of 65 으 until achieve a constant weight to determine dry phytomass of cladodes per plant in an analytic balance $0.001 \mathrm{~g}$ (Silva et al., 2014).
To estimate salinity threshold of each cultivar, the adjustment equation was derived and the interaction graphics of salinity $x$ cultivars were used.

\section{Statistical analysis}

Data obtained were evaluated using variance analysis ( $F$ test) at 0.05 and 0.01 probabilities. For significant effects, linear, polynomial, and quadratic regression were used for 'salinity' factor. Regarding 'cultivar' factor, mean comparison test (Tukey) at 5\% probability was applied using the statistical software SISVAR (Ferreira, 2011).

\section{Conclusions}

Irrigation using saline water with an electrical conductivity of $2.0 \mathrm{dS} \mathrm{m}^{-1}$ or more affects negatively the emission of superior cladodes for all forage palm cultivars evaluated.

Miúda cultivar had the best production of fresh phytomass when irrigated with a saline water of $4.04 \mathrm{dS} \mathrm{m}^{-1}$, followed by Orelha de Elefante Mexicana (2.73 dS $\mathrm{m}^{-1}$ ), and Baiana (2.17 $\mathrm{dS} \mathrm{m}^{-1}$ ).

\section{References}

Alves RN, Farias I, Menezes RSC, Lira MA, Santos DC (2007) Produção de forragem pela palma após 19 anos sob diferentes intensidades de corte e espaçamentos. Rev Caatinga, 20: 38-44.

Bezerra SAF, Silva TGF, Souza LSB, Moura MSB, Morais JEF, Diniz WJSS, Queiroz MG (2015) Demanda hídrica bruta da Palma Forrageira em cenários futuros de mudanças climáticas no Estado de Pernambuco. Rev Bras Geogr Fís. 8: 1648-1653.

Dantas FDG (2015) Lâminas de água salina e doses de adubação orgânica na produção da palma Miúda adensada no semiárido. Macaíba: Universidade Federal do Rio Grande do Norte, Dissertação de Mestrado, $92 \mathrm{f}$.

Dias DS, Blanco F, Souza ER, Ferreira JFS, Souza Neto ON, Queiroz ISR (2016) Efeitos dos sais no solo e na planta e tolerância das culturas a salinidade. In: Gheyi HR, Dias NDS, Lacerda CF, Gomes Filho E (ed) Manejo da Salinidade na agricultura: Estudos básicos e aplicados. 2.ed. Fortaleza: INCTSal, p.151-161.

Donato PER, Pires AJV, Donato SLR, Bonomo P, Silva JA, Aquino AA (2014) Morfometria e rendimento da palma forrageira 'Gigante' sob diferentes espaçamentos e doses de adubação orgânica. Rev Bras Cienc Agrar. 9: 151-158.

Dubeux Júnior JCB, Araújo Filho JT, Santos MVF, Lira MA, Santos DC, Pessoa RAS (2010) Adubação mineral no crescimento e composição mineral da palma forrageira Clone IPA-20. Rev Bras Cienc Agrar. 5: 129 - 135.

Ferreira DF (2011) Sisvar: a computer statistical analysis system. Ciênc Agrotec. 35:1039-1042.

Franco-Salazar VA, Véliz JA (2008) Efectos de la salinidad sobre el crecimiento, acidez titulable y concentración de clorofila en opuntia fi cus-indica (I.) mill. Saber. 20(1): 1217.

Freire JL (2012) Avaliação de clones de palma forrageira (Opuntia e Nopalea) sob irrigação e salinidade. Recife: Universidade Federal Rural de Pernambuco, Pernambuco, Tese de Doutorado, 85f.

Galvão Junior JGB, Silva JBA, Morais JHG, Lima RN (2014) Palma forrageira na alimentação de ruminantes: cultivo e utilização. Acta Vet. Bras. 8:78-85. 
Holanda, JS, Amorim JRA, Ferreira Neto M, Holanda AC, Sá FVS (2016) Qualidade da água para irrigação. In: Gheyi, HR, Lacerda CFD, Gomes Filho E (ed) Manejo da salinidade na irrigação: estudos básicos e aplicados. 2. ed. Fortaleza: INCTSal, p.35-47.

Lacerda CF, Costa RNT, Bezerra MA, Neves ALR, Sousa G, Gheyi HR (2016) Estratégias de manejo para o uso de água salina na agricultura. In: Gheyi HR, Dias NS, Lacerda CF, Gomes Filho E (ed) Manejo da salinidade na agricultura: estudos básicos e aplicados. 2.ed. Fortaleza: INCTSal, p.337349.

Lima GFC, Wanderley AM, Guedes FX, Rego MMT, Dantas FDG, Silva JGM, Novaes LP, Aguiar EM (2015) Palma forrageira irrigada e adensada: uma reserva forrageira estratégica para o semiárido potiguar. Brasília: Embrapa, $62 \mathrm{p}$.

Lima LR, Silva TGFD, Pereira PDC, Morais JEFD, Assis, MCDS (2018) Productive-economic benefit of forage cactussorghum intercropping systems irrigated with saline water. Rev Caatinga. 31: 191-201.

Motta, IS (2016) Calda bordalesa: utilidades e preparo. 2.ed. Dourados: Embrapa Agropecuária Oeste.

Munns R. (2002) Comparative physiology of salt and water stress. Plant, Cell and Envir. 28: 239-250.

Nunes JSL (2015) Características morfofisiológicas e propriedades biofísicas de cultivares de palma forrageira no semiárido brasileiro. Serra Talhada: Universidade Federal Rural de Pernambuco. Dissertação de Mestrado, $61 f$.

Rego MMT, Lima GFC, Silva JGMS, Guedes FX, Dantas FDG, Lôbo RNB (2014) Morfologia e Rendimento de Biomassa da Palma Miúda Irrigada sob Doses de Adubação Orgânica e Intensidades de Corte. Rev Bras Saúde Prod Anim. 16:118130.

Richards LA (1954) Diagnosis and improvement of saline and alkali soils. Washington: U. S. Department of Agriculture. 160p. Handbook 60.

Silva LM, Fagundes JL, Viegas ENM, Rangel JHH, Moreira L, Backes AA (2014) Produtividade da palma forrageira cultivada em diferentes densidades de plantio. Ciênc Rural. 44: 2064-2071.

Silva NGM, Lira MA, Santos MVF, Dubeux Junior JCB, Mello ACL, Silva MC (2010) Relação entre características morfológicas e produtivas de clones de palma forrageira. Rev Bras Zootec. 39: 2389-2397.

Silva RHD (2017) Crescimento de palma forrageira irrigada com água salina. Viçosa: Universidade Federal de Viçosa, Tese de Doutorado, 66f.

Silva TGFS, Araújo Primo JT, Morais JEF, Diniz WJS, Souza CAA, Silva MC (2015) Crescimento e produtividade de clones de palma forrageira no semiárido e relações com variáveis meteorológicas. Rev Caatinga. 28: 10-18. 